\title{
IMPLEMENTATION OF GOVERNMENT POLICIES IN PANDEMIC MANAGEMENT COVID-19 IN INDONESIA
}

\author{
Hasriani Timung \\ Master of Public Health, Faculty of Public Health, Muhammadiyah University of Jakarta \\ E-mail: annietimung.at@gmail.com
}

\begin{abstract}
Introduction: Implementation of government policies in tackling the Covid 19 pandemic in Indonesia is an effort by the government to deal with cases of coronavirus disease (COVID-19). By understanding the efforts, steps, and policies formulated and implemented by the government, it can be assessed the handling strategy. Method: To analyze used deliberative policy analysis approach. This approach analyzes the narratives and arguments of the authorities to understand decision-making and policy implementation. This paper uses a qualitative approach by utilizing descriptive methods of analysis. Meanwhile, the data collection techniques used are literature studies that utilize government regulations, FMD, $K M K, S E$, journal articles, online news as well as the websites of authoritative institutions. The results of this analysis are: first, a positive and negative narrative to the government's response to prevent the transmission of COVID-19 because it has expanded various policies for covidmanagement and formed a task force and task force to combat COVID even though some policies are considered too late. Second, coordination between stakeholders, between the central government and local governments, between ministries and other state institutions already exist in the regulations of their respective ministries but have not been well-coordinated in their implementation so that it seems as if each moves on their own and some seem contradictory. Third, residents are still disobedient, indifferent to the government's call for discipline in implementing health protocols. This results in slower handling efforts because there is no awareness that pandemics can be controlled faster if the community actively provides support. Conclusion: This combination of three factors plays a major role in the government's efforts to control the spread of COVID-19 in Indonesia although it still needs improvement along with the pandemic in Indonesia.
\end{abstract}

Keywords: Policy, Countermeasures, Covid 19 


\section{INTRODUCTION}

Coronavirus Disease 2019 (COVID-19) is an infectious disease caused by Severe Acute Respiratory Syndrome Coronavirus 2 (SARS-CoV-2). SARS-CoV-2 is a new type of coronavirus that has never been identified before in humans. There are at least two types of coronavirus known to cause diseases that can cause severe symptoms such as Middle East Respiratory Syndrome (MERS) and Severe Acute Respiratory Syndrome (SARS). Common signs and symptoms of COVID-19 infection include symptoms of acute respiratory distress such as fever, cough, and shortness of breath. The incubation period averages 5-6 days with the longest incubation period of 14 days. Severe cases of COVID-19 can lead to pneumonia, acute respiratory syndrome, kidney failure, and even death. The rapid transmission process led WHO to designate COVID-19 as KKMMD/PHEIC on January 30, 2020.

About the policy of tackling infectious disease outbreaks, Indonesia already has Law No. 4 of 1984 on Infectious Disease Outbreaks, Government Regulation No. 40 of 1991 on The Recurrence of Infectious Disease Outbreaks, and Regulation of the Minister of Health No. 1501/Menkes/Per/X/2010 on Certain Types of Infectious Diseases That Can Cause Outbreaks and Countermeasures. Therefore, to prevent the COVID-19 outbreak early, the Minister of Health has issued a Decree of the Minister of Health Number HK.01.07/MENKES/104/2020 concerning the Determination of Novel Coronavirus Infection (Infection 2019-nCoV) as a Type of Disease That Can Cause Outbreaks and Countermeasures.

The determination is based on the consideration that Novel Coronavirus Infection (Infection 2019-nCoV) has been declared as a Public Health Emergency of International Concern (PHEIC). In addition, the widespread of COVID-19 to various countries with the risk of spreading to Indonesia is related to population mobility, requiring countermeasures against the disease.

The Government of Indonesia has decreed Presidential Decree No. 11 of 2020 on the Determination of Public Health Emergency Corona Virus Disease 2019 (COVID-19). The Presidential Decree defines COVID-19 as a type of disease that causes a Public Health Emergency (KKM) and establishes THE COVID-19 FAMILY in Indonesia that countermeasures by the provisions of the laws and regulations. In addition, the government also issued Presidential Decree No. 12 of 2020 on the Determination of Non-natural Disasters spreading Corona Virus Disease 2019 (COVID-19) as a National Disaster.

$\mathrm{Kkm}$ countermeasures are carried out through the implementation of health quarantine both at the entrance and in the region. In the implementation of health quarantine in the region, 
after a fairly comprehensive study Indonesia took a policy to implement Large-Scale Social Restrictions (PSBB) which in principle implemented to suppress the spread of COVID-19 is expanding, based on epidemiological considerations, the magnitude of threats, effectiveness, resource support, operational technical, political considerations, economic, social, cultural, defense and security. Psbb regulation is stipulated through Government Regulation No. 21 of 2020 on Large-Scale Social Restrictions to Accelerate the Handling of Corona Virus Disease 2019 (COVID-19) and techniques described in Regulation of the Minister of Health No. 9 of 2020 concerning Guidelines for Large-Scale Social Restrictions to Accelerate the Handling of Corona Virus Disease 2019 (COVID-19).

The Local Government is also expected to strengthen health facilities by involving Local Government Public Hospitals (RSUD), Puskesmas, and Private Hospitals as well as strengthening laboratory systems in their respective regions.

Then in handling Covid-19, the Local Government must maximize pentahelik collaboration (Government, Academics / Experts, Business World, Community / Community, and Media) and involvement to the village/village level including the device (PKK, Karang Taruna, and RT / RW). Before making a decision, the Local Government is expected to form a regional task force first and immediately. Covid-19 management policies and measures should pay attention to the principles of accountability and transparency. Then lastly, the Local Government must pay attention to public safety, inter-regional interests, and national interests.

\section{METHODS}

To analyze used deliberative policy analysis approach. This approach analyzes the narratives and arguments of the authorities to understand decision-making and policy implementation. This paper uses a qualitative approach by utilizing descriptive methods of analysis. Meanwhile, the data collection techniques used are literature studies that utilize government regulations, FMD, KMK, SE, journal articles, online news as well as the websites of authoritative institutions. Descriptive methods of analysis are used because the data and information collected focus on actual phenomena or problems through the process of data collection, preparation, processing, and concluding. The result of it all seeks to describe an empirical state that is objective to the phenomenon or problem being studied. While the data collection technique used is the study of literature. Literature studies are used as data collection techniques due to the limited time provided to conduct in-person interviews. 


\section{RESULTS AND DISCUSSIONS}

Indonesia's responsiveness in overcoming the influx of novel coronavirus into the country gets special credit from the World Health Organization (WHO). According to WHO's Medical Officer for Indonesia, Vinod Kumar Bura, Indonesia's facilities are good and by the standards of the institution. So far, the government has had 100 referral hospitals to deal with cases of new disease infections, such as coronavirus. Hundreds of these hospitals are spread throughout Indonesia. "They have just tested all specimens out of 60 cases in recent weeks and have confirmed that none of them are positive for coronavirus. We are fully confident that this laboratory can detect novel coronavirus," said Vinod at the Health Research and Development Agency (Balitbangkes) of the Ministry of Health, Tuesday (11/2/2020). According to the Head of Balitbangkes Ministry of Health, Siswanto, the method of examination of a novel coronavirus is by WHO standards. Who sets out for laboratory confirmation tests related to coronavirus through two-sample tests. A total of four stages are performed in detecting coronavirus, namely finding the correct suspect; retrieving specimens; transferring the specimen through a "viral transport medium"; to conducting polymerase chain reaction (PCR) using a PCR machine correctly. The laboratory for virus detection was equipped with adequate equipment and skilled experts. Balitbangkes emerging infectious disease national referral laboratory facility has the tools and capabilities to perform serologically, polymerase chain reaction (PCR), Sanger sequencing and next-generation sequencing, flow cytometry and fluorescence microscope, and others. The facility has a safety level for the handling of biological agents or biosafety levels 2 and 3 and biorepository.

Siswanto said the laboratory can test specimens using PCR machines from genetic material contained in specimens, namely RNA. Balitbangkes plays a role in conducting lab confirmation tests to detect viruses. While the results of laboratory tests are submitted to the Ministry of Health. "We are a national reference to new emerging and reemerging diseases. New emerging is a disease that has not appeared before and attacks humans," he said. Vinod's statement came shortly after five researchers from Harvard University researched the spread of the novel coronavirus. In a journal titled Using predicted imports of 2019-nCoV cases to determine locations that may not be identifying all imported cases, it is mentioned that outbreaks due to coronavirus increased dramatically to reach more than 75,000 cases on January 25, 2020, and caused Wuhan City to be isolated. On February 4, 2020, the case became an international outbreak with reports having occurred in 28 countries. One of the countries 
indicated to have contracted it is Indonesia, with reports of one to zero cases. "In Indonesia and Cambodia, which had direct flights from Wuhan during the coronavirus outbreak, the number of cases is below the 95 percent PI limit and has reported one to zero cases to date,"

(Newswire, Andya Dhyaksa, Bisnis.com).

In a post in the online media Suara.Com, Chairman of Disaster and Crisis Journalists (JBK) Ahmad Arief mentioned the Indonesian government since the beginning of the late response to the Covid-19 Virus. In fact, According to Arief, neighboring countries have been vigilance against their citizens in Wuhan City, by responding quickly to the spread of the covid19 virus.

"Almost all of our neighboring countries that have direct travel interactions from Wuhan to these countries have reported positive cases," Arief said in an online discussion on corruption and covid-19 handling issues via video conference on Thursday (04/09/2020). Arief also suggested an oddity, because, from the beginning of December to January 2020, the government stated that it has not detected any coronavirus or Covid-19 entering Indonesia.

Moreover, the condition was exacerbated by the Indonesian government's policy at that time that even opened tourism promotion. In fact, in contrast to Indonesia, neighboring countries have first closed flight access from Wuhan city and China. "We tend to be late. Even when other countries completely shut down travel from China and countries have been infected, Indonesia even promotion of tourism. We are still raising funds for tourism from aviation to hospitality. It shows the policy choices the government took on this issue from the beginning were problematic," he said.

Moreover, coupled with the denial of comments from state officials with various narratives that claim that Indonesia can be free of the covid-19 virus. "For example, Indonesian people are immune, the tropics are safe, and so on. Indeed, the actual narratives are not very to be conveyed by a government."

The Covid-19 Supervisory Team of the House of Representatives visited the Covid-19 Task Force of the National Disaster Management Agency (BNPB) in Jakarta, Friday (8/5/2020). The team provided many inputs to the Task Force to maximize coordination between ministries and institutions in handling the Covid-19 outbreak.

"The Task Force must continue to bridge so that there are no collisions between institutions in ministries and institutions related to the handling of Covid-19," said Member of the Covid-19 Supervisory Team of the House of Representatives, Siti Mukaromah. 
The synergy between the center and the region continued Erma is also very minimal and needs to be maximized. This is evident in some cases as not yet in line between central and regional policies. He assessed the outbreak had an impact on almost all aspects of life. The biggest impact, the economic sector. In this case, the task force has not maximally aggregated the role of civil society including community organizations (ormas). "We hope that the Task Force can be a pioneer in mediating all interests to remove this plague from the face of the earth. The Task Force should integrate ministries and institutions so that there is no misperception between the Ministry and Institutions or between the center and the region so as not to confuse the community," said the politician of the National Awakening Party.

The Supervisory Team also assessed that the implementation of the Social Security Program (JPS) was late, causing unrest in the community. It should be that the aid can be faster and evenly distributed so that those who impact do not get restless so that they are encouraged to return to their villages. (Author: Hasanudin Aco

Editor: Johnson Simanjuntak, Tribune news.com)

Based on the reportage in Liputan6.com, Jakarta, there are still many people who are ignorant of health protocols amid a spike in cases of covid 19. In a big city like Jakarta, not a few people are seen not wearing masks in their daily activities.

Complying with health protocols is the main gateway in efforts to reduce the transmission of covid 19. According to a journalist's report on Friday, February 5, 2021, a motorcyclist who was passing through Matraman, Jakarta, did not wear a mask. Angkot driver was passing through the Raya Bogor area, Jakarta, was seen not wearing a mask. The widespread threat of the spread of COVID-19 is difficult to avoid if the public does not comply with health protocols. Several online ojek drivers are gathering in Senayan, Jakarta also does not wear masks properly. All workers who have potential contact with others should carry out health protocols such as one wearing a mask. Traders are waiting for buyers in the Pasar Rebo area, Jakarta. Unfortunately, there are still traders who do not wear masks. The government is expected to help the lower class to provide masks so that it can be more effective in complying with health protocols.

Jawahir Gustav Rizal wrote in online media kompas.com that the coronavirus pandemic has not passed. So far, there has been no sign of transmission being successfully controlled. New cases of coronavirus transmission are reported to continue to occur every day. The government through the Task Force on Handling Covid-19 has urged the public to carry out $3 \mathrm{M}$ protocols to prevent the transmission of coronavirus. $3 \mathrm{M}$ consists of washing hands, wearing 
masks, and keeping a distance. However, although the situation of the Covid-19 pandemic still does not show signs of improving, the level of community compliance in implementing measures to prevent the transmission of coronavirus is decreasing. Quoted from Kompas.com, Friday (04/12/2020) Spokesperson of the Task Force on Handling Covid-19, Wiku Adisasmito said, the level of community compliance in implementing health protocols continues to decline in November 2020. The decrease in the number of compliance with health protocols began to occur in the long holiday period of October 28-November 1, 2020. The trend continued until November 27, showing that the percentage of people's compliance in wearing masks was only 59.32 percent. Meanwhile, compliance in maintaining distance by 43.46 percent. "If it continues like this then as many health facilities as available will not be able to accommodate the surge that occurred," he said.

In response, The Head of Anthropology Sociology Education Program of FKIP UNS, Nurhadi said, one of the factors that make the level of community compliance to implement health protocols is that there are still people who do not believe that the virus is real. "I suspect there are still many people who to this day deny that the coronavirus is real, and many of them feel that it is not something to worry about," Nurhadi said when contacted by Kompas.com, Friday (04/12/2020). Nurhadi said that some people are more worried about other things, such as losing their job or not being able to eat, rather than being afraid of Covid-19. Nurhadi said that another factor that contributes to the decrease in the level of community compliance to implement health protocols is the inconsistency of the recommendations delivered by the government with the implementation of policies in the field. "People always look at the above (government) in such things. So who gave the example who the hell, if then the told can not give an example, yes people will decrease their trust," said Nurhadi. Moreover, the application of health protocols according to Nurhadi is instructive, whereas people tend not to like when told to let alone forced. According to Nurhadi, the process of socializing health protocols is still not involving figures close to the daily life of the community. "The decision to use the mask is very personal actually, and it can only be intervened by people who are personally close to us," nurhadi said. "So if for example I as a commoner, told the Regent, lha Regent who? People will think that way. Different for example if told Mr. Kiai or Mr. Ustaz in the village, the effect will be more pronounced," he added. Nurhadi argues that the government should be able to embrace local figures, and through these figures make awareness to the community to implement health protocols more effectively. 
Polda Metro Jaya together with the TNI has established a security post in anticipation of the occurrence of crowds in Pasar Tanah Abang Wholesale Center, Central Jakarta. "Regarding the many problems in Tanah Abang market, first we form the police will follow up, we will do community disciplinary to obey the $5 \mathrm{M}$ rules do not let the crowd again there," Said Head of Public Relations of Polda Metro Jaya Kombes Pol Yusri Yunus told reporters in Jakarta, Saturday night, May 1, 2021. Yusri said security forces took the crowd seriously at the site. Therefore, it will also set up a security post on site. The security post was established on Sunday (2/5/2021). Through the security post, the supervision of public health protocols at the site will be tightened.

"Starting tomorrow (today) we will establish a security post there from the police, TNI, and local government there. In the post we prepare masks, we tighten patrols together there to avoid the crowd," he added. The last step taken by officers to prevent crowds at the site is to prioritize the buyer community with wholesale quotas at the location. "We will set the scale of shopping priorities for Tanah Abang Wholesale Market for visitors who buy wholesalers who are usually intercity shoppers. Then the shopper for our urai in a special market that is not selling wholesale," Said Kombes Yusri.

He also asked people who shop at Tanah Abang Market to adhere to health protocols. He said the turnaround of the economic wheels on-site and the implementation of health protocols should go hand in hand. "We keep emphasizing, we encourage the people who shop there to obey the rules of health protocol. Keep your distance, wear a mask, and do not crowd should always be applied," encouraged Yusri. Although some Indonesians have been vaccinated, Yusri said the implementation of health protocols should continue. He warned that the condition of the coronavirus pandemic in Indonesia has not ended at this time until the discipline of health protocols must still be carried out by the public. "The Covid-19 pandemic is not over yet, vaccines are not a guarantee we are not infected. Please do activities, but still disciplined prokes, because discipline is also a vaccine," he said. (Between, Tempo. co).

\section{CONCLUSION}

Corona Virus Disease-19 (COVID-19) is a global pandemic with a very massive spread. Until the end of April, more than 2 million people have been infected with this virus with a death toll above 13,000, and it has spread in 213 countries. This paper analyzes the efforts made by the Government of Indonesia in handling and controlling the spread of COVID-19. To obtain data and information, the authors use data collection techniques from the study of literature. The 
findings obtained from the first author's analysis, positive and negative narratives on the government's response to prevent the transmission of COVID-19 because it has issued various policies to deal with covid and formed a task force and task force for overcoming COVID, although some policies are considered by some to be a bit late. Second, inter-stakeholder coordination, between the central government and local governments, between ministries and other state institutions is already in the regulations of their respective ministries but has not been well coordinated in its implementation so that it seems as if each of them is moving independently and some even seem contradictory. Third, residents are still disobedient, indifferent to the government's call to discipline in implementing health protocols. This results in slower handling efforts because there is no awareness that the pandemic can be controlled more quickly if the community actively provides support. The combination of these three factors plays a very important role in the government's efforts to control the spread of COVID19 in Indonesia, although it still needs improvement along with the course of the pandemic in Indonesia.

\section{REFERENCES}

Ministry of Health of the Republic of Indonesia. Decree of the Minister of Health of the Republic of Indonesia Number HK.01.07/Menkes /413/2020 concerning Guidelines for Prevention and Control of Coronavirus Disease 2019 (Covid-19)

Instruction of the President of the Republic of Indonesia Number 6 of 2020 concerning The Improvement of Discipline and Law Enforcement of Health Protocols in the Prevention and Control of Corona Virus Disease 19.

Agus, Wibowo, Head of BNPB Disaster Information and Communication Data Center, Website of The National Disaster Management Agency

Chandra, Iswinarno | Welly Hidayat, Suara.com, April, 2020

Windi, Wicaksono, Coverage 6, February, 2021

Antara, Dwi Arjanto, Tempo.co, May, 2021

https://lifestyle.bisnis.com/read/20200211/106/1200033/who-puji-indonesia-dalammengantisipasi-virus-corona. Author: Newswire Editor : Andya Dhyaksa https://www.tribunnews.com/corona/2020/05/09/tim-pengawas-covid-19-dpr-ri-kritikkoordinasi-antar-kementerian-dan-lembaga. Author: Hasanudin Editor: Johnson Simanjuntak 


$$
\text { E-ISSN: 2808-5361 }
$$
http://e-journal.fkmumj.ac.id/
Proceeding The First Muhammadiyah Internasional- Public Health and Medicine Conference

https://www.kompas.com/tren/read/2020/12/04/204700765/kasus covid19-terus-uphill-whatcause-society-increasingly-neglect-health protocol Author : Jawahir Gustav Rizal Editor : Sari Hardiyanto 